\title{
Bedret avbildning av medfødte hjertefeil
}

Nye ultralydteknikker gir tilleggsinformasjon om hvordan blodet strømmer hos barn med medfødt hjertefeil.

Det er et stort behov for skånsom og nøyaktig diagnostikk av medfødte hjertefeil, og vi har i dette prosjektet hatt som mål å forbedre avbildning av blodstrøm med ultralyd.

Nye ultralydteknikker for avbildning av blodstrøm er utviklet i Trondheim og baserer seg på sporing av flekker (speckles), som er ekkogene punkter som finnes i alle ultralydopptak. Blodstrømsavbildning (blood flow imaging, BFI) visualiserer dette flekkmønsteret, som er vinkeluavhengig og dermed kan fremstille blodets bevegelse i alle retninger.

I doktorgradsprosjektet mitt ble metoden for første gang testet ved hjerteavbildning. 67 barn i alderen $0-16$ år ble undersøkt, og ulike prober ble testet. Resultater fra undersøkelsene tyder på at blodstrømsavbildning kan gi bedre bilde av lungevener og atrieseptumdefekter hos barn.
I løpet av prosjektet ble metoden videreutviklet. En ny opptaksmetode gjør at bilderaten økes betraktelig, og unike fingeravtrykk i blodstrømsekkoet kan følges over tid (speckle tracking). Dermed kan man nå beregne hastighet og retning på flekkenes bevegelse. Sporing av flekker i blodstrøm (flow speckle tracking) ble validert in vitro og testet klinisk hos nyfødte med septumdefekter. Metoden gir gode hastighetsmålinger og tilfører ny informasjon om blodstrøm. For eksempel avbildes virvler som ikke er mulig å se med tradisjonell fargedoppler.

Vi håper metoden $\mathrm{i}$ fremtiden kan bidra til bedre forståelse av fysiologiske og patologiske prosesser i hjertet.

Siri Ann Nyrnes

sira-nyr@online.no

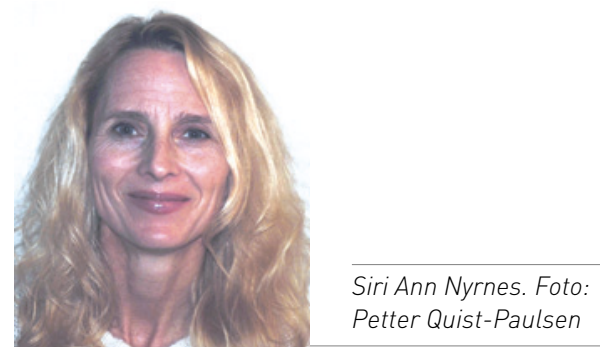

Disputas

Siri Ann Nyrnes disputerte for ph.d.-graden ved Norges teknisk- naturvitenskapelige universitet i Trondheim 24.10. 2014. Tittelen på avhandlingen er New ultrasound flow modalities for evaluation of congenital heart defects.

\section{Resultat av hjertescreening hos fotballspillere er metodeavhengig}

\section{Tolkingen av EKG kan være avgjørende for om en idrettsutøver får klarsignal for videre aktivitet.}

Obligatorisk hjertescreening av fotballspillere i Tippeligaen og Adeccoligaen ble innført i 2008 for å redusere risikoen for plutselig hjertestans og død. Tolking av EKG i screeningstudier har ofte vært basert på personlig erfaring. Nytten av ekkokardiografi har ikke vært undersøkt, og blodtrykksmål er blitt oversett.

I mitt doktorgradsarbeid studerte jeg effekten av å tolke EKG på forskjellige måter hos 595 mannlige elitefotballspillere, og om ekkokardiografi ga viktig tilleggsinformasjon. I en pasient-kontroll-studie fulgte vi også fotballspillere med høyt blodtrykk.

Omtrent dobbelt så mange EKG ble tolket som unormale når programvaremålingene av tidsintervaller og elektriske amplituder ble benyttet, sammenliknet med visuelle målinger av EKG på dataskjermen. Antall unormale EKG ble redusert fra $30 \%$ til $11 \%$ når Seattle-kriteriene (2013) ble benyttet, sammenliknet med kriteriene fra European Society of Cardiology (2010). Ekkokardiografisk undersøkelse av alle spillerne ga ingen viktig tilleggsinformasjon. Mange spillere hadde høyt blodtrykk både dag og natt, og det høye blodtrykket var assosiert med høy hjertefrekvens, høyt pulstrykk og økt indeksert venstre ventrikkelmasse.

Funnene indikerer at det er stort behov for enighet om valg av målemetode og kriterier for unormale funn ved tolking av EKG hos idrettsutøvere. Ekkokardiografisk screening er unødvendig. Høyt blodtrykk hos idrettsutøvere er ikke et uskyldig funn og bør følges opp etter vanlige retningslinjer.

Hilde Moseby Berge

hildemosebyberge@hotmail.com

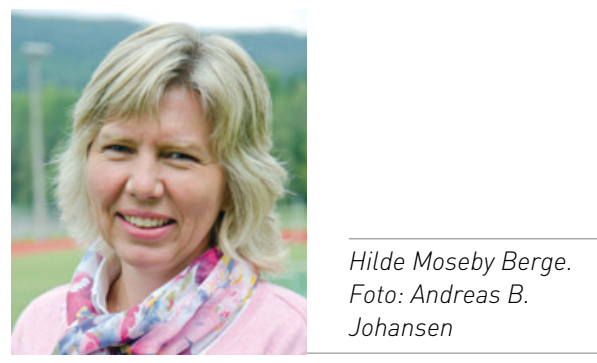

Disputas

Hilde Moseby Berge disputerte for ph.d.graden ved Universitetet i Oslo 23.9. 2014. Tittelen på avhandlingen er The Norwegian athletes' heart: Cardiac screening of 595 professional soccer players. 